\title{
Panji and Sekartaji on the move
}

\author{
LYDIA KIEVEN
}

\begin{abstract}
Since the millenium, the Panji tradition has undergone an increasing process of revitalization and transformation in Java. It shows a broad spectrum of concepts and forms: benefit of a long forgotten cultural heritage, academic approach, popularization, innovation, and its use for strengthening cultural identity. Starting on a grass-roots and community level of artists, intellectuals, and villagers, focusing on the manifestation of values and symbolism, the Panjimania has entered governmental and institutional level throughout recent years, focusing on popularization of art and entertainment in big formats. This boom is also reflected in research and publications on an academic and semi-academic level. The paper discusses the complexity within the state-of-the-art discourse on cultural heritage, for example the risks of instrumentalization, and its major trajectories and potential of this living heritage for the future.
\end{abstract}

KEYWORDS

Culture; tradition; heritage; art; entertainment; tourism.

\section{BACKGROUND}

This paper ${ }^{1}$ is based on my long-term involvement in the process of the revitalization of the Panji tradition in Java, particularly in East Java, which began in the late 1990s. During this process, I have conducted art-historical research on depictions of Panji stories on temple reliefs, besides studying Panji stories in literature and in the performing arts. I have come into contact with local grass-root activists and artists in Java who care about their culture

${ }^{1}$ This article is based on the paper presented in the Panji Panel at EuroSEAS Conference in Oxford on 17 August 2017. Since then the processes being the subject of the paper have undergone major changes which will be considered in this article.

LYDIA KIEVEN is affiliated to Bonn University, Department of Asiatic and Islamic Art History, Germany, and a free researcher. Her fields are ancient Javanese art, and Javanese tradition and culture, with a focus on the forms and developments of the Panji traditions. Major publications are: Following the cap-figure in Majapahit temple reliefs; A new look on the religious function of East Javanese temples 14th and 15th centuries (2013, Leiden: Brill); Menelusuri Panji dan Sekartaji; Tradisi Panji dan proses transformasinya pada zaman kini (2018, Yogyakarta: Ombak). Lydia Kieven can be contacted at: lydia.kieven@gmail.com.

(C) 2020 Faculty of Humanities, Universitas Indonesia

LYDIA| DOI: 10.17510/wacana.v21i1.868. 
and we have developed many different sorts of co-operation, mostly in local communities. The fascination of the Panji theme as local wisdom is the motor driving our enthusiasm. More recently there have been new directions on a governmental level: chief among them a process of acknowledgement of the Panji traditions as an outstanding cultural heritage, leading to the registration of Panji tales manuscripts as Memory of the World (MoW) by UNESCO, which has seen an upsurge in their popularization on a larger and broader scale through the implementation of institutional programmes.

This article describes the long, winding road of the processes of revitalization and transformation, and presents an outlook on its potential in the future. Although the Panji revival is considered and discussed on a national Indonesian and then an international level, the core perspective is East Java. The paper is not the outcome of ethnological fieldwork or classical research. Commencing from a personal perspective, it proceeds to the broader perspective of the mechanisms of cultural heritage management and their challenges. I ask the reader to keep this personal and to some extent subjective approach in mind.

The variety of manifestations of the Panji tradition demonstrates the extraordinary richness of this cultural heritage:

1) Literature: oral versions such as folk tales and written versions.

2) Ancient art: temple reliefs and sculptures.

3) Performing arts: wayang topeng: mask dance in different traditions, for instance, Malang, Yogyakarta, Surakarta, Cirebon; wayang beber: paper scrolls from Pacitan in East Java and Wonogiri in Gunung Kidul; wayang gedhog: shadow puppets play, figures in the style of wayang beber depictions; wayang krucil/klithik: puppets made of wood, the style of the figures similar to those of gedhog and wayang beber.

4) Manuscripts, the majority from the early nineteenth century and thereafter: in Javanese and in the Malay language from Java and Sumatra; a few manuscripts are illustrated with depictions of scenes in wayang beber style.

5) Broader Southeast Asia - Malaysia, Thailand, Myanmar, Cambodia, Laos: dance choreographies, manuscripts, paintings; featuring the names Inao/Enaung for Panji, and Bussabha for Sekartaji.

Detailed research into the Panji theme has been done in extenso elsewhere and partly in this volume. I mention but a few names of pioneering scholars to demonstrate the diversity of research. ${ }^{2}$

\footnotetext{
${ }^{2}$ For more references see the bibliography.
} 
1. The long-time focus of research was in the field of philology, anthropology and history: W. Rassers (1922); R.M.Ng. Poerbatjaraka (1940; 1968); C.C. Berg (1954); J. Ras (1973).

2. Transcriptions and translations of Panji stories: S.O. Robson (1971) on Wangbang Wideya; Karsono Saputra $(1998,2014)$ on Serat Panji Angreni; Noriah Mohamed (2017) on Panji Jayangtilem.

3. Archaeological studies: W.F. Stutterheim (1936a, 1936b, 1938); Satyawati Suleiman (1978); L. Kieven $(2013,2016)$.

4. Performing arts: Th.G. Pigeaud (1938) partly dealing with Panji; C. Brakel (1985, 1993a); L. Ross (2016).

5. Balinese Malat in broader context of Panji theme: A. Vickers (2005).

6. Historical dimension: Vickers (2009).

7. Historico-archaeological aspects: publications by Agus Aris Munandar (1992, 2014) and Agus Aris Munandar and Ninie Susanti (2014).

8. Southeast Asian perspective: Thaneerat Jatuthasri $(2010,2017)$.

9. Open fields of research, for example:

- Oral traditions of Panji stories

- Continuation of research on interdependencies within Southeast Asia - Panji manuscripts: historical aspects, illustrations, symbolism, etcetera - Magic coins with depictions of Panji and Sekartaji (J. Cribb collection at the British Museum; Cribb 1999).

\section{Process of the Revitalization of the Panji tradition}

The Early ReVITALIZATION OF THE PANJI TRAdITION ${ }^{3}$

The revitalization process began on a grass-roots level and in recent years has made its debut on the institutional and governmental stage. At the beginning there were just a few enthusiasts from different fields and backgrounds environmentalists, education, performing arts, ritual, archaeology, history, culture in general - in East Java who were fascinated by the Panji tradition which was on the verge of being lost and forgotten. They initiated activities with various purposes in mind: the re-discovery and preservation of this rich cultural heritage, exploration, and application of its potential for the benefit of the local Javanese people. The "founder" of the Panji movement - the late Suryo W. Prawiroatmodjo, an enthusiastic environmentalist, founder of PPLH (Pusat Pendidikan Lingkungan Hidup) 'Environmental Education Centre' in Trawas 1990 who passed away in 2013 - considered respect for culture to be the equivalent of respect for nature and the environment. His vision was to raise the awareness of the local people of their own culture, so that they could learn to respect it, thereby engendering an attitude of self-responsibility for their culture and environment. Their efforts have to be seen against the background of the repressions during the Soeharto era which suppressed free and independent movements. One group particularly targeted was peasants who had been forced to acquiesce in the "green revolution" introduced by the

\footnotetext{
${ }^{3}$ See a detailed list of activities up to the present in the appendix.
} 
authorities to yield greater crops; the observance of traditional agrarian rituals, just as all kinds of expressions of adat, was tabooed. Suryo W. Prawiroatmodjo encouraged the local rural people to go back to their traditions and, for example, conduct water rituals at natural sources, embracing the Panji theme as a symbol of fertility. Another aspect lurking behind these concepts was the speed with which the processes of globalization and modernization, and - at that time - the early developments in Arabization, all of which considered old traditions as antiquated or opposed to orthodox religious beliefs, was developing. At that time, all kinds of kejawen rituals were being conducted in various secret ways. ${ }^{4}$

The Panji tradition was considered a specific bearer of local genius and local wisdom, and was thought to be particularly suited to be a medium for conveying and enacting these purposes. As it is primarily manifest in folklike forms, it was categorized as part of the culture of common people. Being indigenously Javanese, the Panji arts were thought to be different from the well-known court arts of the palaces in Central Java, which always have been considered as "high art", whereas arts of East Java were considered as simpler and hence inferior. ${ }^{5}$ The Panji arts are not derived from the Indic cultural expressions such as Ramayana and Mahabharata. The Panji tales belong to the kidung genre, while the Indic-based poems are composed as kakawin. The former is characterized by its down-to-earth content and style; ${ }^{6}$ the latter by its more sacral and refined poetic creations. The visual expression of the two genres displays the same dichotomy: the depictions of Panji scenes on temple reliefs display a folk-like, simple character and style, while the kakawin scenes highlight court and divine episodes in a far more stylized way. The separate placement of the two genres of relief depictions in one and the same temple is another factor which has contributed to the dichotomy: Panji tales appear in the lower or entrance parts, kakawin tales in the upper or rear parts. ${ }^{7}$ Panji is imbued with the spiritual symbolism of an intermediary between the mundane world and the Divine in the sacred world (Kieven 2013). As stated by Stutterheim, ${ }^{8}$ the Panji arts should actually be considered as one specific expression of the creative and rich art of Majapahit culture, and absolutely not as degenerative art, as claimed by earlier scholars. The fact that the Panji stories were depicted in sacred spaces is evidence of the high esteem in which they were held by religious and political authorities. The spiritual and ritual character of Panji is reflected in the performing arts: the dancer of wayang

\footnotetext{
${ }^{4}$ See also A. Beatty's (2009) ethnographic descriptions and analysis of changes in religious attitudes and, in particular, in kejawen in rural areas.

${ }^{5}$ Within the new movements in East Java, the long tradition of Panji performances at the Central Javanese court circles, particularly of Surakarta, was initially neglected.

6 " [...] there is a difference to be discerned between the kidung and kakawin literature. The latter, for instance, frequently treats subjects taken from the Indian epics or purana, and but rarely comes 'down-to-earth'”. (Robson 1971: 19).

7 The art of Panji temple reliefs has been studied in extenso by Kieven (2013, 2014a, 2014b, 2016, 2017a, 2017b, 2018). A. Vickers' (2005) study on the Panji Malat also discusses the dichotomy of the two different genres of literature and art.

${ }^{8}$ Several publications by Stutterheim in the 1930s (1935, 1936a, 1936b).
} 
topeng must relinquish his own character and his attachment to worldly affairs; prayers and offerings prior to the performance enhance the ritual character. ${ }^{9}$

A major keyword in the Panji traditions is "creativity": it is manifest in the large number of versions of Panji stories, the Panji arts and rituals, and the many different ways in which the protagonist, Panji, finds himself in his search for ways to cope with life's struggles. Panji and Sekartaji are an example of ideal human values: persevering in their endeavours, overcoming all kinds of hindrances, finding innovative ways to search for each other, eventually, reaching harmony. They demonstrate the universal challenge faced by human beings in life. Even though he is a member of the aristocracy, Panji's attitude in his interactions with rural and common people is another aspect which reveals Panji's ideal character. As a seeker of inner wisdom, Panji acts as a guide in spiritual processes. The external and internal qualities and values of the Panji tradition make it a specific kind of cultural heritage which provides benefit to people in many levels of society.

Suryo W. Prawiroatmodjo created the term "Panji culture" (Budaya Panji). He considered Panji to be an example of local indigenous wisdom, analogous, for instance, to the ancestor cults in Flores. Panji culture was meant to be a label for local and marginalized traditions which are in fact immensely rich. Panji is the example par excellence of the local genius of the ancient East Javanese period, carried on throughout the ages in a variety of forms. The symbolism and role of Panji are still valid today and have an unrivalled potential to strengthen the local people's self-awareness and appreciation of their local culture. Concepts of implementation are manifold: revival/ revitalization, popularization, studies, innovation, and transformation. Suryo W. Prawiroatmodjo and the wider community at the time recognized that the most important means of imparting knowledge is education on all levels of society, with a focus on the young generation. Curricular and non-curricular programmes were initiated for teachers and school-classes.

An initial step in the co-operation of activists was a meeting in 2004 summoned by Suryo W. Prawiroatmodjo. The outcome was the "Festival Panji" in August 2007 as the first major event to address and attract a broader audience. The festival included an international academic seminar organized by Universitas Merdeka Malang, Department of Tourism, a traditional topeng performance at the art stage Padepokan Mangundharmo in Tumpang (Malang district), the performance of a new choreography at PPLH Trawas (Mojokerto district), and an educational workshop in Trawas (Figure 1). Although not gathered under one umbrella, the various individual parts of the festival demonstrated the richness of the Panji forms and perspectives as well as the diversity of actors and their respective backgrounds. These events gave rise to a growing community of Panji enthusiasts, an increase in informal and formal seminars, workshops, dance performances, and publications. The programmes were a manifestation of the aforementioned creativity of the Panji traditions and of the figure of Panji himself.

${ }^{9}$ See also Brakel 1993a. 


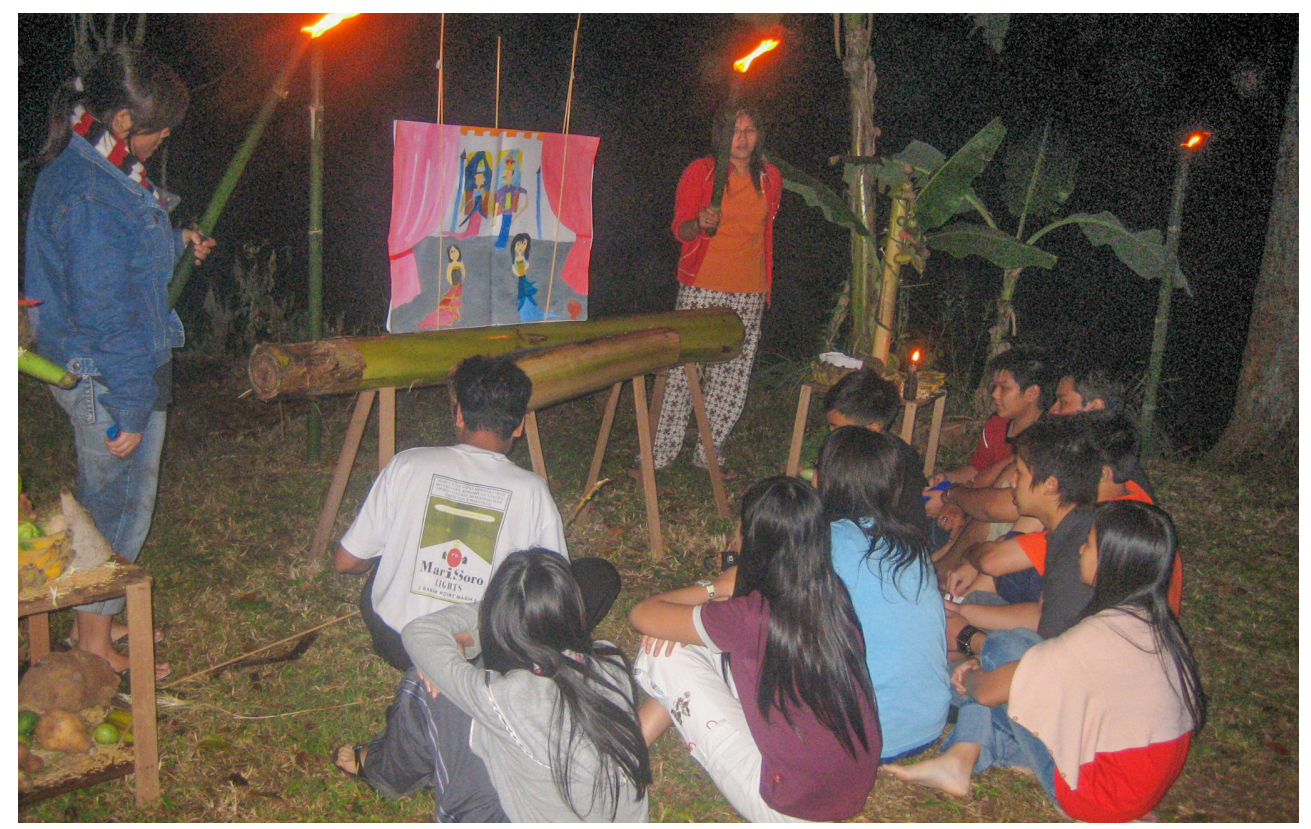

Figure 1. Panji Festival 2007 in Trawas, East Java: Wayang beber workshop for children, conducted by Suryo W. Prawiroatmodjo. (Photograph by Lydia Kieven).

In the early years of revitalization, the emphasis lay on the exploration of the values of the Panji tradition. As the process developed, there was a shift to a broader popularization of the Panji arts to convey their knowledge to a larger public audience, in which the tendency was towards entertainment. The term Budaya Panji was now used as a common label for all manifestations of Panji traditions and arts. The emphasis was placed on the conservation and preservation of the tradition; the inner values tended to be overshadowed. On the academic level, there was an increase in seminars, papers and publications.

\section{PANJI BOOM}

A "Panji boom" began around 2014. As described above, over the years grassroots and independent actors had been working individually and in small-scale networks with local communities in an increasing number of larger public activities. Now, institutions on regional and governmental levels discovered and realized that all the forms of the Panji tradition were a valuable cultural heritage to be preserved. The two developments seem to have happened independently of each other and, initially, actors in the grass-roots initiatives and the institutions did not even know about each other, except superficially. Somehow "Panjimania" had spread.

Initiated by a handful of Panji enthusiasts, in September 2014 there was a meeting of around twenty-five independent actors in East Java, ranging from young people in their twenties to older activists in their sixties. ${ }^{10}$ They

\footnotetext{
${ }^{10}$ Inspired and pushed by friends, I took the initiative of inviting the participants to the meeting.
} 
came from the fields of art, education, journalism, ritual, archaeology, history, and other kinds of culture. The idea of the meeting was to establish a larger, efficient network of individuals and groups, who had so far mostly worked separately from each other and who henceforward could develop synergetic effects to make the Panji traditions and their values better known to the public for the general benefit of society. There was broad discussion on the ways and processes by which to raise awareness of the Panji tradition. These were thought of as five successive steps: knowled ge of the culture, understanding, pride, respect and appreciation, and a readiness to preserve. These steps may yield another step: application and transformation. ${ }^{11}$ With their different backgrounds and talents, all the participants shared a common vision in the implementations. The outcome of this meeting was the plan to improve networking through establishing regional centres and one co-ordination centre and the application of various approaches and methods. Education was considered the principal tool for implementation. An information centre was planned which would provide material in the form of publications, proposals for educative programmes and the like. The meeting adopted the title Pencinta Panji (Panji Aficionados) which was also used in the name of a website and of a Facebook group. ${ }^{12}$ However, after some initial steps, the plans to establish a continuously working centre fell through. Nevertheless, in an informal way networking produced all kinds of activities: traditional as well as innovative arts, educational programmes and the participation of local communities. At that time, the journalist Henri Nurcahyo, who had been active in the Panji movement for years, established the website Budaya Panji which has been continuously posting blogs on present Panji issues and the Facebook group Sahabat Panji dan Sekartaji. ${ }^{13}$ He has become a major motor in the ongoing processes of establishing Panji programmes, organizing seminars and festivals and seeing publications through.

It was through the initiative of the National Library of the Republic of Indonesia (Perpustakaan Nasional Republik Indonesia, abbreviated to PerpusNas), that governmental institutions became stakeholders of the Budaya Panji. In 2013, PerpusNas launched the project to safeguard the oldest Panji manuscript kept in its archive: the Panji Angreni from Palembang composed in 1805. Alongside the plan for the nomination of this manuscript as a Memory of the World by UNESCO, a festival was organized by the National Library in Jakarta in October 2014, including an exhibition of outstanding manuscripts and wayang beber paintings, an academic seminar in the fields of philology, history, archaeology, art, and dance performances. ${ }^{14}$ Later, instead of only the one, PerpusNas decided to select seventy-six pieces from the whole corpus of eighty-one manuscripts of Panji stories kept in its archive for nomination. After

\footnotetext{
${ }^{11}$ These steps conform with processes of dealing with cultural heritage in general.

${ }^{12}$ The private Facebook group Pencinta Panji, which has 431 members and regular posts, focuses on academic and popular discussions on issues related to Panji.

${ }^{13}$ The public Facebook group Sahabat Panji dan Sekartaji, which has 602 members, provides continuous information on current activities.

${ }^{14}$ Proceedings of the seminar (Perpustakaan Nasional Republik Indonesia 2014a).
} 
a series of co-operations with libraries in foreign countries, the application was later revised: the group of Panji manuscripts at the Indonesian National Library, Leiden University Libraries (252), Malaysia National Library (7), and Cambodia National Library (one) was submitted for nomination as a whole corpus to UNESCO. The British Library signed a letter of support. ${ }^{15}$ The goal of all these steps was to attract more attention to the Panji stories manuscripts, in both the scholarly and public worlds. To strengthen support for the nomination, co-operation with other governmental institutions was initiated and organized: the district government of Kediri, the Tourist Department of the Province of East Java, the General Directorate of the Indonesian Culture Ministry. The promotor of this process was Professor Wardiman Djojonegoro, formerly minister of education and cultural affairs. The focus was to convey knowledge about the Panji arts to a wider audience through popularization: a number of large-scale events, including festivals and seminars, held in 2016 and 2017 attracted many visitors. While the first festivals concentrated on the well-known Javanese mask dances, wayang topeng, the more recent festivals in 2018 and 2019 have also included other forms of Panji theatre which had long been forgotten, such as wayang klithik, wayang gedhog, wayang beber, and wayang topeng Jati Dhuwur.

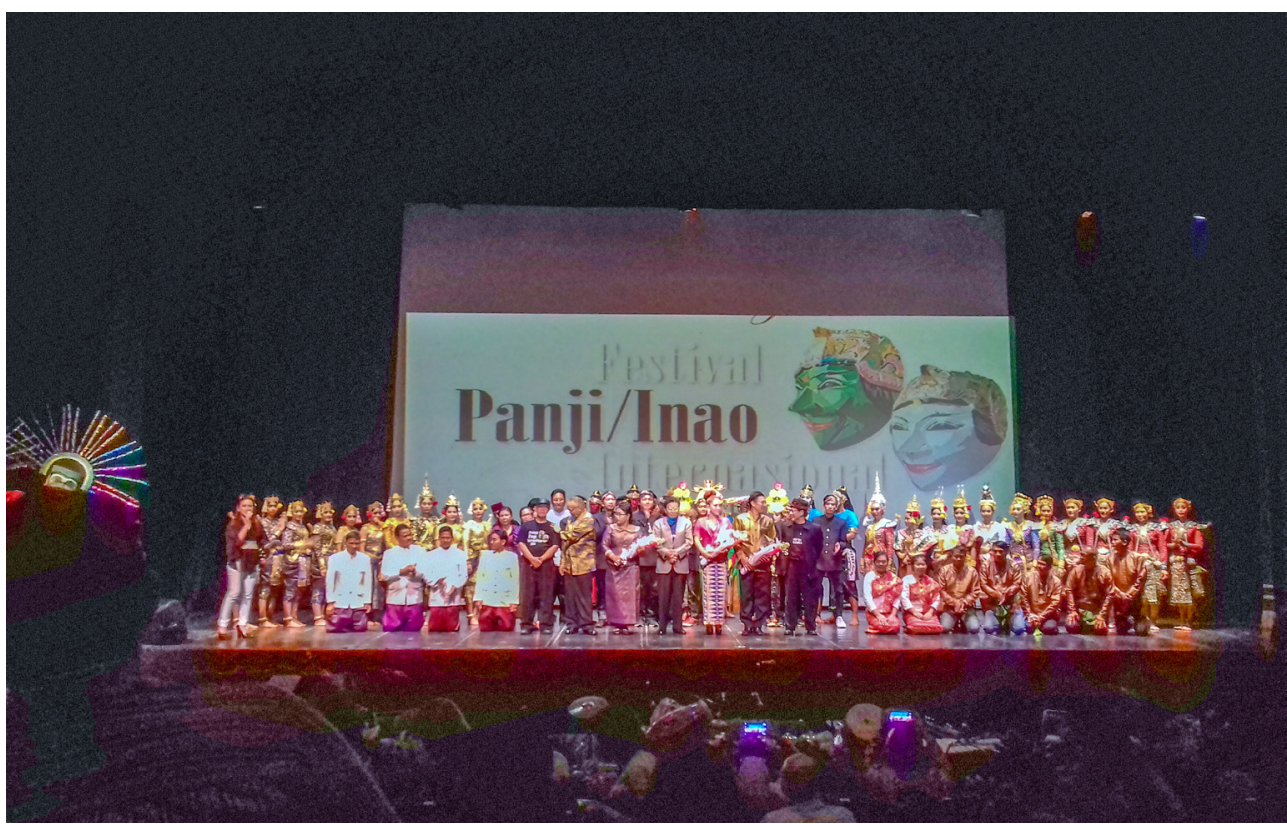

Figure 2. Panji Festival 2018 by Indonesian National Library (Perpustakaan Nasional) and Cultural Ministry, Jakarta: Dance groups from Southeast Asian countries and seminar speakers. (Photograph by Lydia Kieven).

${ }^{15}$ The collections of Panji manuscripts in the German National Library and a few other collections were not considered. 
The Festival Panji in 2018 (Figure 2), celebrating the registration of the Panji tales manuscripts as MoW and consisting of a two-week programme and tour of Bali, East Java, Yogyakarta, and Jakarta, opened the spectrum to the ASEAN perspective by the addition of dance performances from Thailand and Cambodia. However, as these were more or less scaled to art and entertainment, the inner values of the Panji theme tended to be overlooked. The ritual aspect was, however, incorporated in the performance of the newly created cleansing ceremony, Ruwat Panji, at Candi Tegowangi, Kediri District. Obviously, in the course of these annual festivals, economic and tourist purposes have been prominently rearing their heads. ${ }^{16}$ There are plans to conduct alternating national and international Panji Festivals on an annual basis.

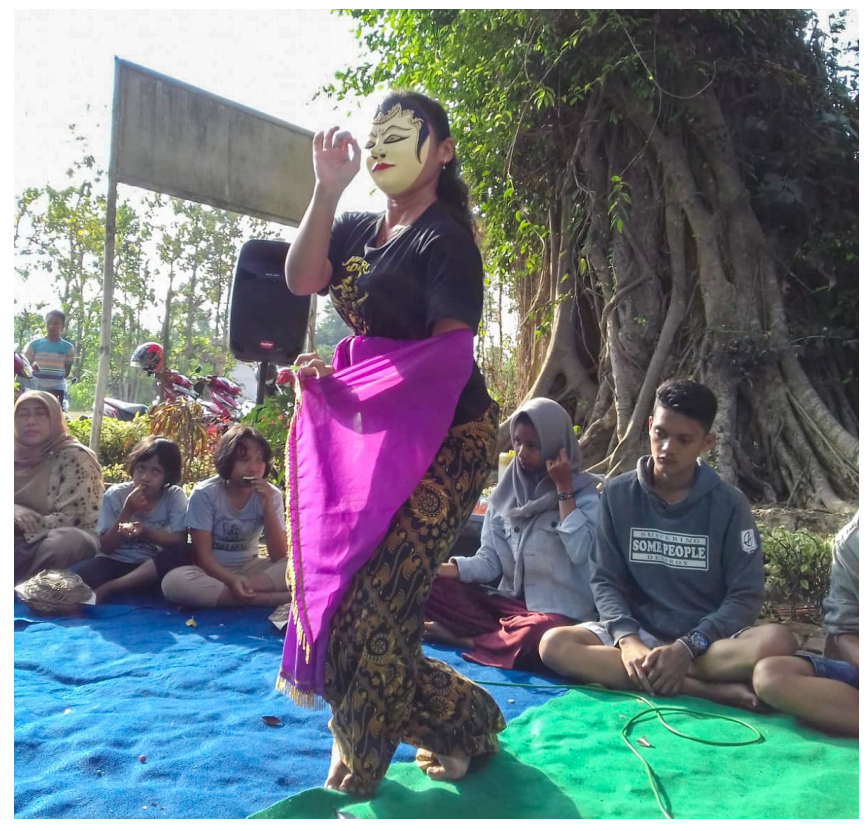

Figure 3. Tulungagung, East Java, Candi Mirigambar 2018: Wayang topeng and discussion on Panji revitalization on local level, conducted by local community Cagar Budaya Tulungagung. (Photograph by Lydia Kieven).

During the years 2014 to 2017, the co-operation and interconnection between independent and governmental actors and institutions developed only marginally. The International Panji Festival 2018, held by the cultural ministry and regional institutions, even caused an uproar in the East Javanese art and cultural communities: many artists and other activists who had already been working in the Panji "movement" for years were not involved. They complained that the selection of artists given the chance to perform traditional dances and new choreographies was not transparent and had been dominated by the protegés of governmental or regional authorities; a number of "Panji activists" were not invited or even given access to the events. The National Festival in 2019 was

${ }^{16}$ This topic will be discussed in Section IV. 
expected to integrate more independent artists. Despite this intention, certain groups who had applied to contribute to the programme were not accepted. There was even a flare-up in the competition within local communities who had been active on a voluntary basis and those who were now hired by government institutions. Time will tell how these developments pan out (Figure 3).

In their specific ways both sides of the coin do and will contribute to making the rich Panji heritage better known to the public and to fostering cultural identity. The programmes operate on all levels of society: local communities, artists, and cultural actors, in curricular as well as extra-curricular education, in academic circles and among governmental stakeholders.

There have been recent developments in the re-discovery of long-forgotten traditions and the initiation of new forms of enactment. They have occurred in both in independent and institutional programe, in some cases in synergetic ways. For example, the wayang forms wayang beber, wayang krucil/klithik, wayang gedhog, wayang topeng Jati Dhwwur, all of them presenting Panji stories, have undergone a revival. The first performance of wayang beber on a large stage was given by Rudhi Prasetyo at the International Panji/Inao Festival in Bangkok 2013. In Pacitan, one of the "homes" of wayang beber, ${ }^{17}$ several lines of re-enactment have emerged, each of them claiming the authorization to continue the genealogically legitimized tradition. ${ }^{18}$ Both a traditional and a contemporary form have been performed during the last few years. A cooperation between the artist Dani Iswardana from Solo and Ganjar Abunawas, a dalang of wayang beber in Pacitan, has integrated social critique and traditional art. For many years the Indonesian Art Academy (Institut seni Indonesia = ISI) in Solo has been offering classes in painting in the wayang beber style, but only recently has it been taken notice of by the "Panji world". Since his retirement, the former ISI teacher Bambang Suwarno, ${ }^{19}$ a dalang of wayang kulit and wayang gedhog, has created new forms of wayang Panji. The Museum Wayang Beber Sekartaji in Bantul/Yogyakarta, which has an exhibition of wayang beber paintings and holds workshops for children, is another outcome of this development. Wayang gedhog, a shadow play using puppets in its own idiosyncratic style, different from wayang purwa, and wayang krucil/klithik with wooden flat puppets are yet other examples of recent revitalizations. Old and newly carved puppets are both used. The number of dalang and the number of carvers has been growing. Today performances are held in East and in Central Java. All of the kinds of wayang described here, have recently attracted the

\footnotetext{
${ }^{17}$ Traditional wayang beber is known in two areas: Pacitan on the south coast of East Java in the village of Gedempol/Danurejo, with the Panji story Joko Kembang Kuning, and in Wonosari, Gunungkidul, Yogyakarta district, with the Panji story Remeng Mangunjaya.

${ }^{18}$ The situation between family members, villages, the role of the local government and individual artists is very complex. Supani Guno Darmo, a member of the Donorojo family which owns the original set of wayang beber Joko Kembang Kuning, has only lately begun to act as dalang. The late Ki Mardi, who passed away in 2010, was the last dalang in the direct lineage of the Donorojo family and, in his final years, had only rarely performed the wayang beber even though, during the 1970s and 1980s, there were still regular performaces on certain occasions. ${ }^{19}$ See his article on wayang gedhog in Surakarta style, Bambang Suwarno (2014).
} 
interest of young scholars at universities, for example, in Malang, Kediri, Yogyakarta, and Solo; their research will yield new academic insights into the fields of art and history. A number of these innovative and transformative programmes and concepts will be discussed in Section IV.

East Java is not the only region to have "re-discovered" the Panji tradition and its potential. A long tradition of Panji mask dances has existed and been performed in court circles in both Surakarta and Yogyakarta and in villages, for example, in the Klaten region. However, since the 1980s/1990s, there has been marked decline in the performances, particularly in the rural areas. ${ }^{20}$ Evidence of Panji performances in court circles in Surakarta has been broadly discussed by Brakel (1993b). ${ }^{21}$ Partly completely independently of but partly motivated by the developments in the Panji revitalization in East Java and partly out of the growing attention being paid to cultural heritage in general and ultimately coeval with the rise of the "Panjimania" in Java, the performance of the Panji arts in Central Java has undergone a revival and been receiving greater attention over the last few years. Exhibitions and a publication on wayang beber and on topeng Panji, initiated by Balai Soedjatmoko (Surakarta) in 2013 and 2014, festivals, seminars, and research have been caught up in this process. The number of Panji topeng dance performances at the courts of Surakarta and Yogyakarta have increased. The style is rather refined compared to the Malang topeng style with its more down-to-earth character. ${ }^{22}$ Javanese people tend to categorize the court Panji dances as halus (refined) and the Malangan style dances as kasar (coarse). The dynamics in Central Java are quite different from those in East Java, certainly to some extent because of the dichotomy between the court and rural arts. My article puts the focus on the East Javanese revitalization process in East Java, going along with a stronger rural character of the Panji tradition; an encompassing outline of the Central Javanese process must be the subject of another study.

Another centre of the Panji mask dance tradition is Cirebon, with specific traits different again to those in Central and East Java. Cirebon has also seen a tendency towards revival in practice and research; the Indonesian choreographer Endo Suanda is one of a number of artists active in this process. The publication by Laurie Ross (2016) is a comprehensive presentation of the Cirebon topeng history and symbolism.

All the processes described are reflected in academic circles and publications. The volume Konservasi budaya Panji (edited by Henri Nurcahyo 2009) brought the Panji theme to the attention of Indonesian academic and popular audiences. Adrian Vickers' (2009) study of the function of the Panji stories in the Pesisir Culture has opened up and contributed to a broader perspective beyond Java and Majapahit. My own study of the Panji reliefs on ancient East Javanese temples (2013 in English, 2014/2017 in Indonesian) with

\footnotetext{
${ }^{20}$ For Panji from Bobung see Hermanu (2012).

${ }^{21}$ She quotes Javanese treatises describing court dances by the mature and young Panji by the king and the crown-prince. See also the contribution in this issue by Brakel-Papenhuyzen.

${ }^{22}$ See also for the wayang topeng tradition in Tumpang region, Malang: Pigeaud (1938: 143).
} 
a special focus on the symbolic meaning has been another major contribution. ${ }^{23}$ Academic and more popular seminars and conferences, publications - some of them in combination with Panji festivals - bear witness to mounting attention and a vibrant interest. ${ }^{24}$ Since 2014 , the academic programmes organized in the framework of the "Panji tales manuscripts as Memory of the World" initiative have contributed to further scholarly work and publications (for example, Perpustakaan Nasional Republik Indonesia 2014a), as have the Panji Panel at EuroSEAS Conference at Oxford 2017. A few translations of Panji stories have been published by Universitas Indonesia and by the PerpusNas (Karsono Saputra 1998, 2014; Perpustakaan Nasional Republik Indonesia 2014b) and by the Malaysian scholar Noriah Mohamed (2017). Young researchers, national as well as international, have been doing studies or are currently conducting research on, for example, wayang beber, wayang topeng, wayang gedhog, and wayang krucil. The outcomes will hopefully be continued in the future and be made available to a larger public. This Panji double issue of Wacana, Journal of the Humanities of Indonesia (Vol. 21 Nos. 1 and 2) is another major contribution.

The "Panji movement", "Panji world", "Panji enthusiasts", and the "Panji community" who are frequently mentioned in this paper are not clearly defined. They denote a heterogeneous conglomerate of people not limited by any set boundaries. It has grown over the last two or three decades, assisted by people who have been or have become active in initiatives and programmes on the various levels described in this paper. They encompass rural as well as urban dwellers, educated as well as less-educated people, local versus regional versus national and even international circles. Some of them are acting independently of each other, others co-operate in networks; some act on a private basis, others on local community level or institutional and governmental levels. Some have taken initiatives on their own, others have been stimulated and motivated by friends or activists; others have been appointed to undertake the work. Very recently a part of the group Pencinta Panji, founded in 2014, has begun holding discussions about improving, stimulating, and exploring the roots of the revival by putting an emphasis to the complex immanent values of the Panji theme; they want to launch an initial implementation in 2020.

\section{HERITAGE, TRADITION, AND INNOVATION}

\section{GENERAL DISCUSSIONS ON HERITAGE}

The processes discussed above have to be seen against an increased interest in and awareness of cultural heritage on the global stage. Both the local genius and universal values inherent in culture have been the object of intense academic discourse over the past two or three decades. Unquestionably,

\footnotetext{
${ }^{23}$ Thanks to the Indonesian edition in 2014, it reached a broad readership in Indonesia. In 2017 Gramedia published a second print-run with a different title (see Bibliography). First print: 1,500 copies; second print: 1,500 copies, 670 sold by February 2020.

${ }^{24}$ Ardus Sawega 2013, 2014; B. Prasetya Hanggar and I Wayan Dana 2014; Henri Nurcahyo 2015; SEAMEO 2017; Kieven 2018.
} 
globalization has changed and modified behaviour and attitudes on all levels of life, as most societies are eager to participate in the global modern world. This has been counterbalanced by a rise in the appreciation of local culture by local communities and by institutions, in response to and/or as a counter to globalization, recently labelled "glocalization" (Roudometof 2016), meaning the integration of "localization" and "globalization". I shall briefly present the major positions and controversies, before transferring them to the discussion of the Panji heritage.

The process of awareness of cultural heritage has been fostered by UNESCO's programmes of world heritage. The UNESCO Convention of Cultural and Natural World Heritage, which was set up in 1972, was principally based on the desire to safeguard endangered properties considered outstanding cultural masterpieces of mankind. These are material properties, such as archaeological sites and historic buildings and places, for example, Borobudur Temple (1992) in Indonesia. Later the importance of immaterial heritage was also taken into the equation and led to the UNESCO Convention on the Safeguarding of the Intangible Cultural Heritage in 2003. ${ }^{25}$

The definition in the convention says:

1. The "intangible cultural heritage" means the practices, representations, expressions, knowledge, skills - as well as the instruments, objects, artefacts and cultural spaces associated therewith - that communities, groups and, in some cases, individuals recognize as part of their cultural heritage. This intangible cultural heritage, transmitted from generation to generation, is constantly recreated by communities and groups in response to their environment, their interaction with nature and their history, and provides them with a sense of identity and continuity, thus promoting respect for cultural diversity and human creativity. For the purposes of this Convention, consideration will be given solely to such intangible cultural heritage as is compatible with existing international human rights instruments, as well as with the requirements of mutual respect among communities, groups and individuals, and of sustainable development.

2. The "intangible cultural heritage", as defined in paragraph 1 above, is manifested inter alia in the following domains: (a) oral traditions and expressions, including language as a vehicle of the intangible cultural heritage; (b) performing arts; (c) social practices, rituals and festive events; (d) knowledge and practices concerning nature and the universe; (e) traditional craftsmanship. ${ }^{26}$

The process of establishing this convention was not founded on the premise of safeguarding, but focused on questions of the ownership and authenticity of intangible heritage, debates about copyright and competition, the role of local communities and of institutions. The initial motor was driven by debates

\footnotetext{
${ }^{25}$ There has been criticism of UNESCO concepts as European-based and marginalizing cultures in other parts of the world.

${ }^{26} \mathrm{Http}$ // / unesdoc.unesco.org/images/0013/001325/132540e.pdf.
} 
about the indigenous Bolivian song El Condor Pasa, an old anti-colonial protest-song, and its modern "re-use" as an American pop-song by Simon and Garfunkel in the 1970s and its perceived exploitation by modern Western culture. ${ }^{27}$ An essential question was raised about the benefit of this specific expression, ranging from imparting a sense of cultural identity to yielding commercial profit. ${ }^{28}$

In the early years of managing material cultural heritage, the major emphasis was placed on safeguarding endangered properties, implemented by static conservation. Later the concept of safeguarding immaterial/intangible heritage was turned to the natural processes of changes in tradition and support for these processes. This holds true both on the UNESCO level and on independent heritage management. Actually, conservation is a contradiction in itself: if tradition is museumified, it becomes "dead", instead of being kept "alive". "A civilization which tends to conserve is a civilization in decline. Pierre Boulez, 1975" (Lowenthal 2015: 413). ${ }^{29}$ Tradition and heritage are per se living and subject to change. Tradition as a living heritage inevitably includes innovation; the two ideas are not mutually exclusive (Lowenthal 2015: 147). In the context of my discussion, I prefer to use the term "tradition" rather than "culture". The first includes change and innovation in Lowenthal's sense, while "culture" has a stronger connotation of remaining static. ${ }^{30}$

Over time, the concepts and methods of management of both tangible and intangible heritage have undergone developments and changes. Economics, tourism, political and personal prestige have been the motors for the instrumentalization of heritage properties, mostly executed on institutional or governmental levels. Popularization through entertainment and conservation has emerged as the preferred method of implementation, a process - which in its extreme forms - has been labelled "disneyfication" and "museumification" ${ }^{31}$ Intrinsic values are often neglected and discarded from the programmes.

For a long time, the academic discourse on heritage issues concentrated on the UNESCO concepts and their impacts. ${ }^{32}$ However, over time the discourse has shifted in the direction of a critical look at the use of the label "heritage"

\footnotetext{
${ }^{27}$ Valdimar Hafstein 2007: 77-80.

${ }^{28}$ Academic publications are numerous. To mention but a few: articles in G. Fairclough (2008), in particular: C. Holtorf (2008); D. Byrne (2008); in L. Smith (2009); in Hemme and Tauschek (2007); Southeast Asian perspective: H. Dahles (2001); M. Hitchcock (2010). The World Intellectual Property Organization (WIPO) which had already been established in 1967, parted away from UNESCO in the mid-1980s, has been dealing with ownership and exchange while UNESCO's focus is on safeguarding (see for example: Hafstein 2007).

${ }^{29}$ Lowenthal 2015 is an update of the first edition Lowenthal 1985, which is considered a classic and pioneering publication in the field.

${ }^{30}$ Discussions on "culture" and "tradition" see for example the roundup in Byrne (2008: 150151). I do not wish to go into the related discourse here.

${ }^{31}$ On "disneyfication" see, for example, L. Matusitz and L. Palermo (2014); on "museumification" see, for example, R. Kurin (2004).

${ }^{32}$ See, for example, articles in Hemme (2007). A specific critique was that UNESCO policies were Western-oriented and -centred, and did not comply with needs of non-Western countries.
} 
as "UNESCO world heritage". The question was raised asking whether "heritagization" is actually beneficial, or if it might not even have negative effects on society (Hemme 2007). This issue has gained wide currency in discussions about the impact of heritage tourism and of tourism in general (Hitchcock 2010). The label "heritage" has led to an inflation: it is prestigious for a country to collect a large number of UNESCO awards, rather than to take steps to safeguard what is valuable - quantity matters more than quality. In the meantime, the range of discussion is not only restricted to UNESCO heritage, but has broadened to all levels of local cultural heritage, characterized by the same processes.

A crucial factor in the increase in heritage awareness has been the growing desire for and need of a local identity in the globalized world. This leads the localization of cultures, a process which has been labelled "glocalization": global flows and local cultures (Roudometof 2016). The "re-discovery" and "re-raise" of local cultural expressions have led to programmes of retraditionalization and re-vitalization in many societies, often synonymous with re-ritualization. ${ }^{33}$ The majority of these have been initiated and subsequently put into practice by local communities, and implemented in manifold creative forms. In many cases these programmes and concepts have later been taken over by institutions and thereafter have been prone to instrumentalization by commerce or status. "Local knowledge", a term used by Geertz (1983) to open insights into heritage property from the inside, has recently been reconsidered. The role of local communities has been more heavily highlighted in the discourse, and applied in concrete concepts and programmes. This stands in stark contrast to many cases in the early years of UNESCO programmes in which local communities were completely ignored or excluded. Now the genuine implementation and use of local knowledge are encouraged by local agencies through social action. "People are seen not as inheritors or passive recipients of culture but as active owners and modifiers of culture" (Byrne 2008: 162).

The processes in the revival of the Panji theme must also be considered against the background of the recent religionization in Indonesia over the last twenty years or so. This phenomenon has contributed to a strengthening of Islam ("Islamization" or "Arabization"), but also to a revitalization of local religious traditions (adat) (Gottowik 2018: 395-396, referring to Davidson and Henley 2007). Both processes seem to contradict each other, but nevertheless reinforce each other reciprocally. For example, the traditional Javanese kejawen ritual practices are opposed, even attacked, by radical Islam, nevertheless these practices have even been strengthened.

A specific impact of the "re-discovery" of tradition has been a change in people's perspective on the past: the glorification of the past might be a sideeffect or perhaps deliberately initiated, embracing concepts of a "golden age", alterations in historiography, nostalgic creations of myths and legends and

${ }^{33}$ See, for example, C. Brosius and K. Polit (2011). 
authentic "tradition". ${ }^{34}$ The "past in the present" is a label which has frequently been bandied about in heritage discourse. The mixture of fact and fiction is significant to the "cultural memory" of a community. ${ }^{35}$ An excellent source on these issues is Lowenthal's (2015) classical book The past is a foreign country.

\section{INDONESIAN EXAMPLE OF CULTURAL HERITAGE}

The examples below detailing a specific Indonesian case reflect the aspects mentioned in the previous section and present a platform on which to present considerations about the Panji heritage. Dahles (2001) discusses the process of heritage concepts and management during the late period of the Soeharto era: "The New Order government recognized the advantage of ethnic revival for the marketing of the country as a tourist destination, both for domestic and international visitors" (Dahles 2001: 6). The "peak cultures" were sedulously stressed to heighten their contributions to national culture, at the expense of "inferior culture". "Ethnic" /"regional" cultures were delegated to the provinces as local environments. Post-Soeharto saw a development of new perspectives, particularly after the establishment of otonomi daerah kabupaten (autonomy of regional districts) in 2004, focusing on smaller local environments and entities within the provinces. It took a while, however, beginning in the mid-2010s, before "regional culture" was unearthed by kabupaten authorities (department of culture and tourism) as local heritage and was properly begun to be appreciated, hence no longer dismissed as "inferior culture". The potential for defining local identity was put into practice under the slogan warisan budaya lokal (local cultural heritage) and by the implementation of public programmes. Critical aspects in this process have been the dominance of official stakeholders over local communities, competition and claims to ownership and authenticity between kabupaten, even in the inner circles of independent activists and groups. ${ }^{36}$ The tendency to forego inner values for sake of entertainment and emphasis on art has been another common consequence.

The UNESCO-related and the regional perspectives have been characterized by corresponding mechanisms. Whereas the national government acts as promotor and manager of the respective cultural heritage on the UNESCO level, the provincial or district government acts on the regional level. Beyond these processes, local grass-roots communities are free to enact their concepts and programmes independently of institutions and authorities.

For a very long time, Borobudur Temple was one of the major UNESCO world heritage properties in Indonesia (registered in 1991) and was promoted as national heritage in tourist programmes during the Soeharto era. This

${ }^{34}$ Lowenthal (1985, revisited edition 2015). A selection of chapter titles "nostalgia: dreams and nightmares; benefits and burdens of the past; ancients vs moderns: tradition and innovation; knowing the past; remaking the past" are self-explanatory.

${ }^{35}$ Compare J. Assmann (1997: 52): “Der Unterschied zwischen Mythos und Geschichte wird hier hinfällig". See also Lowenthal (2015: 367-378) (Chapter "History, fiction, and faction").

${ }^{36} \mathrm{See}$, for example, the issue of the wayang beber in Pacitan. Wayang beber educative programmes in Mojokerto, mentioned later, counterbalance this competitive situation. 
conforms to a "tendency for nation states to begin to think of themselves as possessing a 'heritage' [...] in the form of cultural capital" (Byrne 2008: 159, referring to Anderson 1991). Up to the present, as one of Indonesia's major tourist destinations, Borobudur attracts domestic and international visitors. However, the character of this Buddhist temple as a specific expression of Javanese history and religion is neglected; its true nature is not explored and presented to the public, although it has been the subject of a host of academic works. Most visitors only have a scant knowledge of its historical and sacred meaning, and use the temple building as an object for photos and the background for selfies, and perhaps simply to document that they "have been there". The inhabitants in the neighbourhood of the temple were evicted when the Borobudur Tourist Park was constructed. The upshot was that local communities which had performed their traditional rituals there throughout the ages were excluded and not involved at all. They were allowed to work as vendors and had to pay when they wanted to visit "their" temple. Ethnologists have stated that Borobudur is "dead" (Hitchcock 2010: 18), although it looks very lively as thousands of visitors climb up and down the staircases. In a nutshell: Borobudur has been instrumentalized for purposes of prestige, economy and tourism.

Another specific example, although not registered on the UNESCO list, is the development of the classical court dance, the bedhaya of Surakarta and Yogyakarta. ${ }^{37}$ A number of controversies, even contradictory aspects have emerged in this process. In the past, the sacral dances, restricted to inner court circles, had been performed in a ritual context and were imbued with a symbolic meaning. Soekarno, considering the bedhaya a relic of feudal times, stated that court culture should be democratized and had it performed in public. Later, under the New Order, its tourist potential was "discovered". Two different ideologies produced the same result: the performances were opened to the public. The duration of the dances was shortened, so that the audience and tourists would not become bored and would have the time to continue their tight sightseeing programmes. The major emphasis was on conveying an impression of a precious art tradition in a condensed form. This led to a decrease in the quality of the dances; but, paradoxically, the teaching of classical dances in academies and art schools was intensified, producing a standardization of a high-quality art form. In both cases, however, the outcome was the neglect of the genuine qualities of sacredness, rituality and symbolic meaning. As a kind of contradiction, a mystical aura has sometimes been deliberately created as a means to make the performances even more attractive to spectators, for example, by prayers and offerings. The stories around the classical dance tradition and its history have often been wrapped in mystery, producing a mingling of historical facts and myths. The bedhaya developments demonstrate the glorification of the past for the purpose of

\footnotetext{
${ }^{37}$ To mention but a few scholars who worked on this topic: F. Hughes-Freeland (2006, 2008), Brakel-Papenhuyzen (1992), Sri Kuhnt-Saptodewo (2007).
} 
glorifying the presence. ${ }^{38}$ Still, in recent years on certain occasions related to court traditions, the bedhaya has been performed at the courts of the Susuhunan in Solo and the Sultan in Yogyakarta in its traditional lengthy form.

\section{The PANJi TRADITION AS CULTURAL HeRITAGE ${ }^{39}$}

The re-discovery of the Panji traditions and arts is a typical example of the general awakening of awareness of and interest in local cultures, in Indonesia particularly since the fall of Soeharto. The Panji tradition has been recognized as an expression of local indigenous Javanese culture which had long been almost forgotten. As part of an indigenous folk culture which had been marginalized over decades as "inferior culture" in the terminology of the pre-Reformasi period, its richness of content, forms, and values has now been unearthed and appreciated. It had been relegated to being the antithesis of the "peak cultures" of the Central Javanese court arts and the famous ancient temple buildings, which have their roots in Indic culture. The folklike character of the Panji arts and more generally all forms of arts of the East Javanese period had already been dismissed as an expression of "degenerate" culture compared to the Central Javanese arts by early researchers of the colonial period although, thanks to Stutterheim $(1925,1989)$, the richness and values attributed to the former had begun to be paid more appreciation.

In fact, the first steps in the process of the revitalization of the Panji tradition in the late 1990s was rather a "rebirth" rather than just merely a being "kept alive" as an endangered tradition; importantly the latter is a major claim in safeguarding heritage. Fostering the pride of local society in its own culture as a means of strengthening cultural identity had already been a fundamental target in the early concepts and activities of the Panji enthusiasts. Although at this stage of proceedings, the UNESCO concepts were not explicitly taken into account by the local activists, their ideas and visions actually did match the concepts enshrined in the UNESCO convention of intangible heritage which "means the practices, representations, expressions, knowledge, skills [...] that communities [...] recognize as part of their cultural heritage. [...] and provides them with a sense of identity and continuity, thus promoting respect for cultural diversity and human creativity" ${ }^{40}$ Pertinently, besides epitomizing the dichotomy of "inferior" versus "peak" cultures, the other major meaning and importance of the "Panji culture" 41 theme has been seen as a paradigm of the plight of local identity in the maelstrom of globalization. The revival of the Panji tradition is therefore an example par excellence of "glocalization".

Creative forms of innovation, transformation and education had been

\footnotetext{
${ }^{38}$ Compare references to Lowenthal and Assmann mentioned above.

${ }^{39}$ I use the term "Panji tradition" because of its connotation of change rather than the term "Panji culture", whose original meaning as a label for local cultures in general has been obscured and later used as a common label for any manifestations of Panji arts and cultural expressions of the Panji theme. See my earlier discussion in Section IV "General discussions on heritage".

${ }^{40}$ See the complete quotation of the definition of Intangible Cultural Heritage by UNESCO above.

${ }^{41}$ Here again meant in the original sense of Budaya Panji.
} 
developed and introduced throughout the years and the Panji tradition was in fact already being enacted as a living heritage. Even a cursory glance shows that Lowenthal's (2015) ideas and concepts could be discovered in it. Again it should be highlighted that these early steps in its enactment were the work of individuals and groups not attached or connected to institutions, hence their visions and activities were inspired and conducted from the "inside" Geertz' sense (1983) mentioned above.

The process of the registration of the Panji stories manuscripts on the UNESCO list of MoW was the outcome of an endeavour to raise public and international appreciation of Indonesia's rich culture, epitomized by its outstanding literary legacy. It was considered a follow-up to earlier listings of manuscripts as MoW: such as the Babad Diponegoro in 2013 and the Kakawin Nagarakrtagama (Desawarnana) in 2013. As mentioned in passing earlier, this process is part of the endeavours of the National Library, which since the 2010s has been working out a mandate for giving the public more access to its rich collection in an attempt to drum up more appreciation for its collection, of which its outstanding new premises, opened in 2017, are an outstanding example. ${ }^{42}$ When searching for other manuscripts thought appropriate to be entered in the MoW in the Library Collection, the Panji tales manuscripts struck a chord as another example of the rich Indonesian tradition of oral and written literature. ${ }^{43}$ The Panji tales manuscripts and their values, which were known only to a limited audience of scholars, were unearthed and "re-born", in a way similar to the initial steps of unearthing and reviving being taken by the independent activists in the late 1990s. The acknowledgement of the Panji tales manuscripts by UNESCO in October 2017 says:

The Panji tales are stories from the 13th century telling the many adventures of the Prince Paji [sic], a Javanese hero searching for his beloved Princess Candra Kirana, and his undertaken in various disguises and with a range of different names, before the lovers are reunited. They mark the development of a Javanese literature no longer overshadowed by the great Indian epics the Ramayana and Mahabharata which were known in Java from the 12th [sic!] century. During the Majapahit empire (14th-15th centuries), the Panji stories became extremely popular, spread by sea merchants, became one of the most popular literatures in Southeast Asia during the 17th-18th centuries, from Java to Bali, the Malay world, Thailand, Myanmar, Cambodia and probably the Philippines. Its influence was described by Adrian Vickers as "a Panji civilization in Southeast Asia". The literary traditions and wider culture of the Panji Tales spread beyond the island of Java to South East Asia, and was and remains a unique regional literary and cultural treasure.

(Http://www.unesco.org/new/en/communication-and-information/memoryof-the world/register/full-list-of-registered-heritage/registered-heritagepage-7/panji-tales-manuscripts/).

\footnotetext{
${ }^{42}$ The library has been equipped with the latest facilities and is attracting an increasing number of visitors and users since its opening in 2017.

${ }^{43}$ The initial suggestion by Dina Isyanti, at the time the head of the special collection (kepala layanan koleksi khusus), was only the Panji Anggreni manuscript from Palembang. See above.
} 
The vision of the Memory of the World Programme is that the world's documentary heritage belongs to all, should be fully preserved and protected for all and, with due recognition of cultural mores and practicalities, should be permanently accessible to all without hindrance.

1. To facilitate preservation, by the most appropriate techniques, of the world's documentary heritage.

2. To assist universal access to documentary heritage.

3. To increase awareness worldwide of the existence and significance of documentary heritage.

(Https://en.unesco.org/programme/mow).$^{44}$

The "Panji culture" in its present sense of comprising all the various manifestations which draw their inspiration from Panji, far beyond just manuscripts, has since been popularized in festivals and public seminars. Awkwardly this has led to a mutual blurring of two specific manifestations: the UNESCO MoW programme referring to the Panji stories manuscripts and the general Panji culture. However, it seems that the difference has not been evident to the majority of the public audience. More importantly, these programmes have been significant and meaningful contributions to fostering knowledge and appreciation of the richness of the Panji tradition and, through this "heritagization", the Panji tradition has been upgraded to a "peak" cultural expression.

"Panji" has now become as an important feature in national culture, as shown by the name "Festival Panji Nusantara" in 2017; the figure Panji is being promoted as a national hero. The "International Panji Festival" in July 2018 highlighted the spread of the Panji tradition to other areas in Indonesia and in Mainland Southeast Asia. This was done with two purposes in mind: reinforcing national pride because of Java is incontestably the primordial root of the spread of this specific cultural expression and because Panji is now being considered a common link in the history and culture of the ASEAN countries. So far "Indianization" had been considered the common link in history, most notably embodied in the Hindu and Buddhist legacy shared by most of Southeast Asian countries (in pre-Islamic times). In contrast, the Panji culture can be considered as indigenous culture, created and developed independently of Indian culture. This potential was highlighted in the SEAMEO-SPAFA programme in 2013 which presented the Panji/Inao-heritage. In Thailand, for example, the Inao-tradition has been very much present for more than two centuries and hence did not need to be "re-born" ${ }^{45}$ Having become the topic of academic discussion, the trans-ASEAN perspective and importance were now ushered into a wider awareness within Indonesia itself through the programmes instigated by the Cultural Ministry of Indonesia. "A Panji

\footnotetext{
${ }^{44}$ UNESCO established the Memory of the World Programme in 1992.

${ }^{45}$ Major academic work from the broader Southeast Asian perspective of the Panji stories has been conducted by Vickers (2009) with his study on the Pesisir culture as the connecting link in the spread of the Panji theme. Studies on the Thai Panji/Inao-traditions have been conducted by T. Jatuthasri $(2006,2010,2017)$ and by D. Puaksom (2007).
} 
civilization in Southeast Asia“, coined by Adrian Vickers (2005: 14), has frequently been quoted.

Now that two major lines developed in the Panji revitalization process: independent grass-roots level on a small scale and the institutional governmental level on a large scale, the time has come to go into the major differences, interrelations, and challenges of the complex developments. One crucial aspect of the early revitalization programmes and concepts has been the value of the Panji theme as local wisdom and culture in a globalized society, inseparable from the figure Panji himself as an expression of ideal human behaviour. It has been thought that the look at these values from the "inside" has been the motor which has inspired "active owners and modifiers" (Byrne 2008) on a local community level to initiate and enact the process of revitalization in various forms to be continued and modified throughout the years. However, the recent developments imposed by the authorities is far more strongly tinged with the "outside": the Panji theme has been recognized as a bearer of rich cultural expressions and put "on stage" as entertainment; the inner values have so far been revealed only as no more than a glimpse. The process of the popularization of the "Panji culture" is treading the familiar path in the natural mechanisms in heritage management, particularly of intangible heritage: large events, in some cases reeking of "disneyfication", attract the masses and are instruments in creating commercial and prestige. Politics have taken over the Panji culture on multi-levels: individuals, cities, regions and the nation. Undeniably, both lines do in fact contribute to raising the awareness of and appreciation by audiences and society, in their respective ways and impacts. The crucial question is: who benefits?

Claims of ownership, authenticity, and competition, as "natural" steps in the heritage processes, are extremely important factors. Examples are: the wayang topeng of Malang; Kediri as "Bhumi Panji"; the topeng Jati Dhuwur of Jombang. The case of the wayang beber is very complex: the question of who is the rightful and legitimate heir to and performer of wayang beber in Pacitan, the question of authentic wayang beber in either Kabupaten Pacitan or Kabupaten Wonogiri. The term "cultural heritage" / warisan budaya had become very popular since the early 2010s in the wake of the establishment of otonomi daerah. Each kabupaten (district) now seeks to determine an own local cultural heritage defining its identity. The hari lahir kabupaten (anniversary of the foundation of the district) has emerged as a popular occasion on which to demonstrate the idiosyncrasy of the respective region. Another competition issue is the fact that Malaysia also has a Panji tradition but Indonesia claims to own the authentic one.

Developments in the Panji arts have parallels to the development of Borobudur: inherent values versus tourist attraction. Will the Panji tradition be able to nurture its multi-dimensional values or will it become "dead", devoid of soul and spirit? (Hitchcock 2010: 18) Do performances, which create an aura of mysticism by using ritual elements such as offerings and prayers, only pretend to be sacral or do they truly want to exploit the original immanent 
ritual meaning and function of the Panji theme? An example is the Ruwat Panji conducted at Candi Tegowangi: has this ancient site, which actually has no connection to Panji, been instrumentalized for an artificial enactment of a mystic aura or is it imbued with a "genuine" ritual spirit? Comparison with the development of the bedhaya dance, moving away from the sacral and ritual character of the performance to artistic entertainment, is fraught with similar conundrums. The symbolic and ritual function of the Panji arts has been ignored or omitted in the large-scale events; the need to comply with the demands of tourism might lead to the standardization of the quality of the art. Conversely, the artistic quality might actually be enhanced by teaching at art academies and schools. New choreographies of Panji dances in recent festivals have demonstrated their creativity as a living heritage. There is more than one side to a coin.

In the past, the ritual aspect was immanent in all kinds of performances, such as wayang topeng and wayang beber, especially when held in villages. Often, they were an integral part of bersih desa rituals (cleansing of the village). ${ }^{46}$ The spiritual aspect was manifest in the dedication of the topeng dancers who strive to go beyond their own identity once they put on their mask. There are "new" rituals at ancient sites, for example, created and conducted by Suprapto Suryodarmo ${ }^{47}$ who does not declare them as genuine tradition, but says they are a continuation and transformation. Today there is yet another aspect: in several performances the ritual aspect has even been deliberately omitted in order not to challenge the radical religious beliefs of those who are opposed to "heathen" practices. ${ }^{48}$

The enactments of the Panji traditions have become a platform for demonstrating manifestations of the "past in the present". Panji as the outstanding example of Majapahit creativity and, as a symbol of the unity of the Majapahit realm through uniting the two competing kingdoms Janggala and Kediri ${ }^{49}$ has been assigned the role of the Majapahit hero. Panji is used as a label for the glorification of and nostalgia for Majapahit as the "golden age" of Indonesia. He has been constructed as "the" representative of Majapahit. The title "Panji Nusantara", which has been used for recent festivals and public presentations, harks back to the name nusantara, which is mentioned in the Nagarakrtagama (1365 CE) and interpreted as a synonym, albeit anachronistic, of present-day Indonesia. By representing the city and district of Kediri as the "home" of Panji ("Bhumi Panji"), based on the role of Kediri as the kingdom of the Princess Sekartaji and of its historic importance, a new historiography and glorification of the Kediri period has been created: faction and fiction intermingle. The village of Gambyok in the Kediri district has been designated

\footnotetext{
${ }^{46}$ See the article by Brakel-Papenhuyzen in this issue.

${ }^{47}$ Suprapto Suryodarmo, dancer and creator/practitioner of free movement (gerakan bebas) from Surakarta, passed away in December 2019.

${ }^{48}$ See my remarks on religionization above in the Section "General discussions on heritage".

${ }^{49}$ However, it seems there are also certain Panji stories which emphasize the opposite: historically friendly relations between these realms. See the article by Brakel-Papenhuyzen in this issue.
} 
"Dusun Panji", reinforced by exposing its one single Panji relief standing next to a Muslim grave as an outstanding material manifestation of the Panji history of Kediri. The handicraft production of souvenirs, like miniature Panji masks as keyring pendants, has been designated ekonomi kreatif, a popular slogan today as Indonesian policy is to promote tourism and the tourist economy.

Remarkably, the development of the revitalization of the Panji tradition has diverged from most other cases of heritage revivals. The process of revitalization taking place on the local grass-roots level had been underway for a long period of more than ten years before institutions and the government tapped into the potential of this rich culture, in the form of the manuscripts. Unquestionably, the institutions did make some use of the long-term practices of the independent activists but the two divergent lines still assumed their specific own methods. Generally speaking, local communities have not been involved as equal partners in the larger programmes and have only been selected as partners by institutional agents to be integrated in them. On the other hand, there are also local artists who explicitly do not want to co-operate with the authorities.

In a nutshell, I have pinpointed a polarization between quantity versus quality, the view from the outside versus the view from the inside. Again, there are more facets to the prism than only these two. All the mechanisms developed for dealing with the Panji heritage are characterized by the same features, be they on a local, regional, provincial or on national levels.

A specific and unique form of the Panji revival is the Panji Museum in Malang district, founded by the culture enthusiast and collector Dwi Cahyono and opened to the public in late 2017. There has been some controversy about its concept and target, whether its focus is on tourism or on conveying knowledge of and pride in the Panji theme. For example, a swimming-pool apparently marking the museum complex as tourist destination has been criticized for having no connection at all with Panji. According to the owner, however, it is a strategy to attract people to visit the museum and learn about Panji, and even get a "plus" by enjoying themselves. Other smallscale museums thematizing Panji have been opened, such as: Keboen Kopi Karanganyar in the outskirts of Blitar or the Museum Sekartaji Wayang Beber in Bantul/Yogyakarta; all of them have their own strategies of combining learning and enjoyment.

Programmes for creating new forms of enacting the Panji theme have been numerous over the years and go beyond the mere "revival". To mention but a few examples: A group of musicians from Blitar has created pop music using a re-construction of a musical instrument, the reyong, which is depicted on the Panji reliefs at Candi Panataran. They have transformed elements of the Panji theme from an ancient into a contemporary art. Dani Iswardana and other artists in Surakarta make paintings in the wayang beber-style, in which they draw attention to critical issues in urban society and environment. Ganjar Abunawas in Pacitan has created the wayang beber sakbendino, with daily performances (from mid-2016 to mid-2017) of wayang beber paintings by Dani Iswardana, in a traditional presentation - gamelan music, suluk dalang - as 
well in contemporary forms with pop music. Jantur Panji Udan by Agus Bimo Prayitno in Klaten / Central Java (Figure 4) is based on the idea of conveying the values of the characters and stories of Panji and Sekartaji, such as not ignoring common people, not giving up in the struggles of life, searching for and achieving harmony; own creations of wayang puppets and innovative forms of performance, sometimes without the usual wayang screen and with music based on village traditions, are being enacted in rural environments; the aim is to convey local knowledge and install pride in the villagers and integrate them as participants, thereby motivating them to take responsible roles as actors in society.

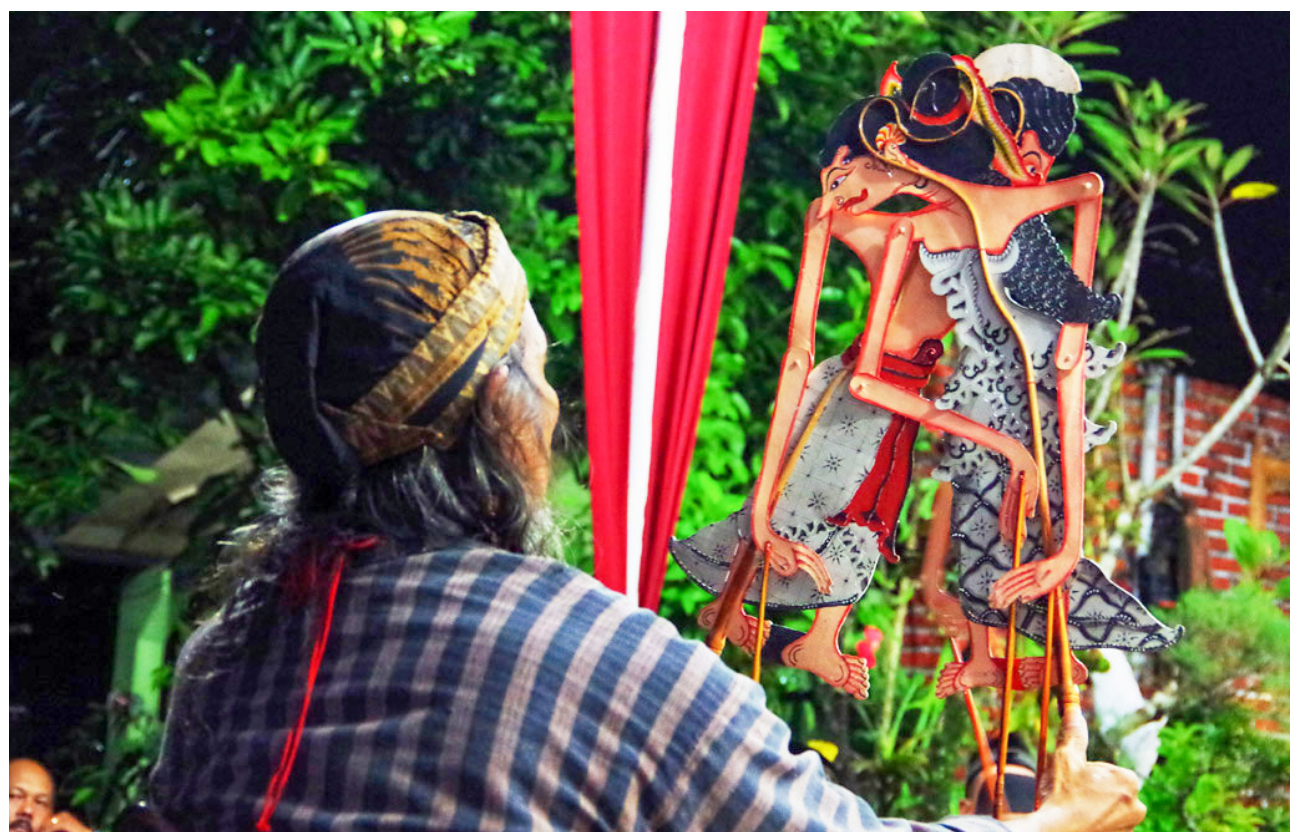

Figure 4. Klaten, Central Java 2016: Performance of Jantur Panji Udan. Wayang figures depicting Panji and Sekartaji, creation by Agus Bimo Prayitno. (Photograph Bambang A. Wenzel).

In Mojokerto district, on the initiative of Arief Budi Santono, a group of art teachers has become very active in organizing wayang beber workshops, four or five times a year, partly in co-operation with the artist Dani Iswardana from Solo: schoolchildren work over several weeks to make paintings in the wayang beber style, write songs and, in a culminating event, they perform their co-operative creation. One remarkable aspect is the fact that in this way the monopoly on the wayang beber held in Pacitan and Wonogiri has been broken; actually this complies with the evidence that the wayang beber was popular in Majapahit and existed in many places in Java. ${ }^{50}$ These and many

${ }^{50}$ For research and facts on wayang beber see Serrurier (1896); Mills (1970); Anderson (1974); Kant-Achilles, Sheltmann, and Schumacher (1990). See also the article by Adrian Vickers in this issue. 
other recent forms are manifestations of the ongoing processes of innovation, transformation and application - in the Indonesian language expressed in the term pengejewantahan - thereby in fact making Panji a living heritage, both in art and values.

As mentioned above, on an academic level, research, seminars, conferences and publications have been growing over the last few years and will certainly deliver more valuable expertise in various disciplines and on different levels. More research still needs to be done about the regional ASEAN perspective; the Panji Seminars in Bangkok in 2013, in Jakarta in September 2018, and in Bangkok in June 2019, were organized with this broader view in mind. A number of other fields are providing topics for deeper intercultural research: discourse on cultural heritage and an intercultural look at myth and storytelling in a universal scope. Popular publications, material for curricular and extra-curricular education (Figure 5), new literary forms and the like will also make important contributions in exploring and developing the Panji traditions to new levels.

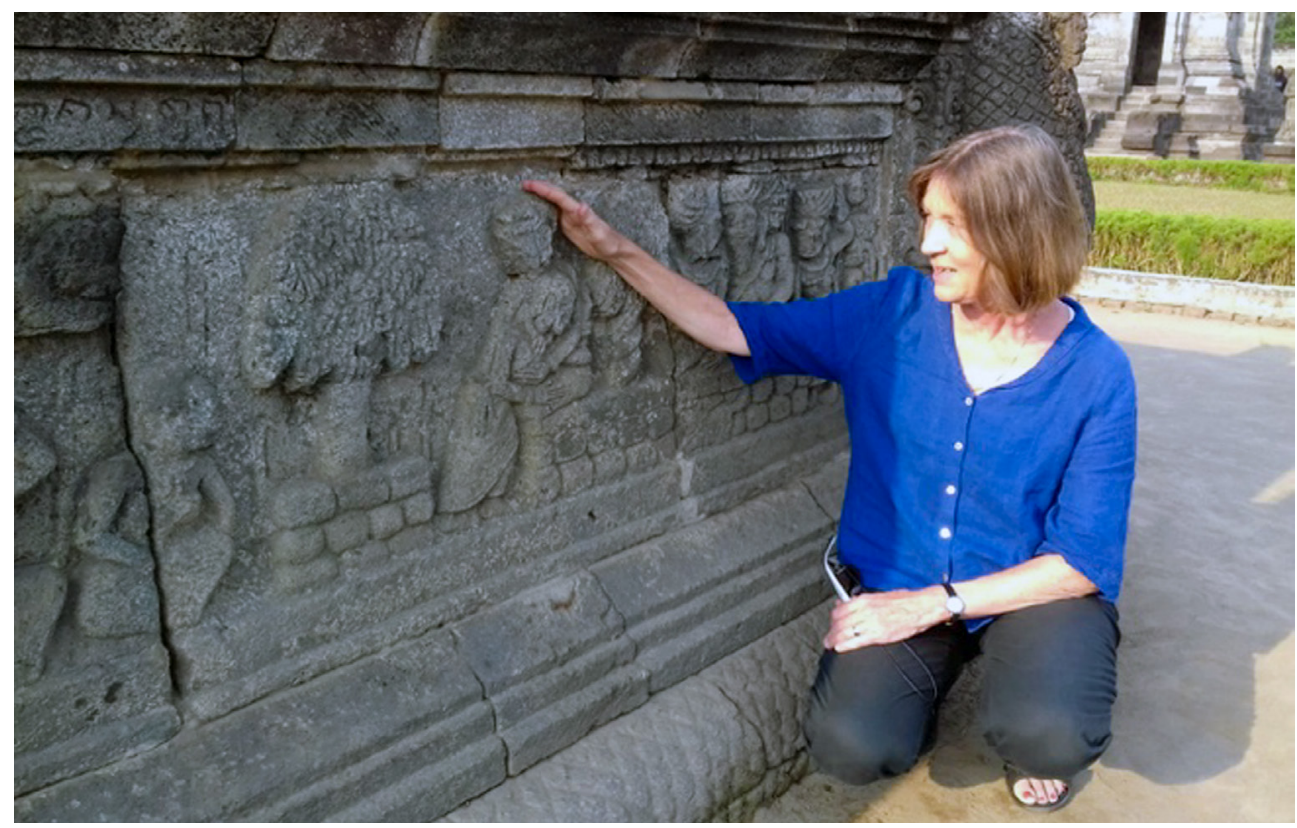

Figure 5. Blitar, East Java, Candi Panataran 2019: Workshop with school-class from Talun, Blitar, detecting and analysing Panji reliefs on the Pendopo Terrace, guided by the author. (Photograph by Kholam Shiharta).

To round up: activities and concepts on all levels of society and institutions and in a broad range of disciplines are contributing to revitalizing a precious cultural heritage. The upshot has been an increase in the knowledge, awareness, pride, appreciation, safeguarding and transformation. It is the responsibility of each party of stakeholders to determine the topics, targets and the ways of implementation. 
This begs the question of whether the "Panji culture" even complies with the UNESCO convention on intangible heritage and whether it is appropriate to be registered on the list. Although many of the earlier mentioned categories have indeed been fulfilled, it seems that, in the wake of its MoW registration and the concomitant activities, the claims of UNESCO intangible heritage have actually already been met and there is no need of a further heritage label.

\section{Potential of the Panji traditions as cultural heritage}

At the present time there is a crucial momentum for the further development of the Panji tradition. Stakeholders have options as well as a responsibility to enact and transfer the potential of this rich cultural heritage - in ways and forms of arts, creativity, entertainment, transformation, education, tourism, research, publications, formal as well as informal discussion groups, TV shows, comics, contemporary art, rituals, tours to historical places and the like. The future is rich in the potential for change and innovation and the continuation of the Panji tradition. The various forms and ways of enactment should stimulate, motivate and inspire the public, in particular the younger generation, to continue to delve deeper into the specific potential of the Panji tradition. A key role in this endeavour is education, both in curricular and in extra-curricular programmes and materials. Two other key roles are the active integration of participants, to balance up the passive recipients of entertainments, and the integration of local communities into the initiation of and development of programmes. The benefit is awareness of its own culture in all levels of society, with the impacts discussed in this paper.

The manifold forms and manifestations of the Panji theme in tradition and transformation make it an outstanding example of a living heritage.

\section{BIBLIOGRAPHY}

Agus Aris Munandar. 1992. "Citra Panji dalam masyarakat Majapahit akhir", Lembaran Sastra: Seri Penerbitan Ilmiah No. 17: 1-16.

Agus Aris Munandar. 2014. "Panji dan para kadeyan mengembara dalam Kebudayaan Nusantara", in: B. Prasetya Hanggar and I Wayan Dana (eds), Prosiding Seminar Tokoh Panji Indonesia; Panji dalam berbagai tradisi Nusantara, pp. 3-19. Jakarta: Direktorat Jenderal Kebudayaan dan Direktorat Pembinaan Kesenian dan Perfilman.

Agus Aris Munandar and Ninie Susanti. 2014. "Makna cerita Panji", in:

Perpustakaan Nasional Republik Indonesia, Prosiding Seminar Naskah Kuna Nusantara "Cerita Panji sebagai warisan dunia" in Jakarta, 28-29 Oktober, pp. 5-19. Jakarta: PerpusNas.

Anderson, Benedict. 1974. "The last picture show; Wayang beber", in: Proceedings of the Conference on Modern Indonesian Literature in Madison, Wisconsin, 28-29 June 1974, pp. 33-57. Madison, WI: Center for Southeast Asian Studies, University of Wisconsin.

Anderson, Benedict. 1991. Imagined communities. London: Verso. 
Ardus M. Sawega (ed.). 2013. Wayang beber; Antara inspirasi dan transformasi. Surakarta: Balai Soedjatmoko.

Ardus M. Sawega (ed.). 2014. Topeng Panji; Mengajak kepada yang tersembunyi. Surakarta: Balai Soedjatmoko.

Assmann, Jan. 1997. Das kulturelle Gedächtnis. München: C.H. Beck. [Recent edition 2013.]

Bambang Suwarno. 2014. "Cerita Panji dalam pertunjukan wayang gedhog gaya Surakarta", in: Perpustakaan Nasional Republik Indonesia, Prosiding Seminar Naskah Kuna Nusantara "Cerita Panji sebagai warisan dunia" di Jakarta, 28-29 Oktober, pp. 283-294. Jakarta: PerpusNas.

Beatty, Andrew. 2009. A shadow falls; In the heart of Java. London: Faber and Faber.

Berg, C.C. 1954. “Bijdragen tot de kennis der Panji-verhalen", Bijdragen tot de Taal-, Land- en Volkenkunde 110: 189-216, 305-334.

Brakel, Clara. 1985. "Javaanse maskerdansen en het Panji-thema: een probleem belicht vanuit de theaterpraktijk in Javaanse dorpen", Scenarium Vol. 9: 56-72.

Brakel-Papenhuyzen, Clara. 1992. The bedhaya court dances of Central Java. Leiden: Brill.

Brakel, Clara. 1993a. "Masked dances, spirit worship and the introduction of Islam in Java", Assaph No. 9: 19-28.

Brakel, Clara. 1993b. "Character types and movement styles in traditional Javanese theatre", in: B. Arps (ed.), Performance in Java and Bali, pp. 59-72. London: SOAS.

Brosius, Christiane and Karin Polit. 2011. Ritual, heritage and identity; The politic of culture and performance in a globalised world. New Delhi: Routledge India.

Byrne, Denis. 2008. "Heritage as social action", in: Fairclough et al. (eds), The heritage reader, pp. 149-173. London: Routledge.

Cribb, Joe. 1999. Magic coins of Java, Bali and the Malay Peninsula; A catalogue based on the Raffles collection of coin-shaped charms from Java in the British Museum. London: British Museum Press.

Dahles, Heidi. 2001. Tourism, heritage and national culture in Java. Leiden: IIAS.

Davidson, Jamie S. and David Henley (eds). 2007. The revival of tradition in Indonesian politics; The deployment of adat from colonialism to indigenism. London: Routledge.

Fairclough, Graham et al. (eds). 2008. The heritage reader. London: Routledge.

Geertz, Clifford. 1983. Local knowledge; Further essays in interpretive anthropology. New York, NY: Basic Books.

Gottowik, Volker. 2018. "Pilgrims, prostitutes, and ritual seks", Bijdragen tot de Taal-, Land-en Volkenkunde 174: 393-421.

Hafstein, Valdimar. 2007. “Recognizing intangible cultural heritage”. [Paper, presented at the International Seminar on Principles and Experiences of Drawing Up ICH Inventories in Europe, Tallinn, Estonia, 14 May 2007; https://ich.unesco.org/doc/src/00195-EN.pdf.]

Hanggar, B. Prasetya and I Wayan Dana (eds). 2014. Prosiding Seminar Tokoh Panji Indonesia; Panji dalam berbagai tradisi Nusantara. Jakarta: Direktorat Jenderal Kebudayaan dan Direktorat Pembinaan Kesenian dan Perfilman. 
Hemme, Dorothee, Markus Tauschek, and Regina Bendix. 2007. Prädikat "HERITAGE"; Wertschöpfungen aus kulturellen Ressourcen (Studien zur Kulturanthropologie/Europäischen Ethnologie). Berlin: Lit.

Henri Nurcahyo. 2009. Konservasi budaya Panji. Surabaya: Dewan Kesenian Jawa Timur.

Henri Nurcahyo. 2015. Memahami budaya Panji. Sidoarjo: Pusat Konservasi Budaya Panji.

Hermanu (ed.). 2012. Panji dari Bobung. Yogyakarta: Bentara Budaya.

Hitchcock, Michael et al. (eds). 2010. Heritage tourism in Southeast Asia. Copenhagen: Nias.

Holtorf, Cornelius J. 2008. "Is the past a non-renewable resource?", in: Fairclough et al. (eds), The heritage reader, pp. 125-133. London: Routledge. Hughes-Freeland, Felicia. 2006. "Constructing a classical tradition; Javanese court dance in Indonesia", in: Th.J. Buckland, Dancing from past to present, pp. 52-74. Madison, WI: The University of Wisconsin Press.

Hughes-Freeland, Felicia. (ed.). 2008. Embodied communities; Dance tradition and changes in Java. New York: Berghahn.

Jatuthasri, Thaneerat. 2006. “Unakan: A combination of the images of Thai hero and heroine", Manusya: Journal of Humanities Vol 9 No 2: 81-94.

Jatuthasri, Thaneerat. 2010. "Thai and Lao Panji stories; Connection with distinction", The Journal 6/2 (December): 27-46.

Jatuthasri, Thaneerat. 2017. "Inao of King Rama II; The transformation of the Panji stories into a masterpiece of Thai court drama literature", Proceedings of the Conference "The Panji/Inao traditions in Southeast Asia, Bangkok 2-6 March 2013". [SEAMEO-SPAFA; http://www.spafajournal.org/index. php/spafajournal/article/view/576.]

Kant-Achilles, Mally, Friedrich Seltmann, and Rüdiger Schumacher. 1990. Wayang Beber; Das wiederentdeckte Bildrollen-Drama Zentral-Javas. Stuttgart: Franz Steiner Verlag.

Karsono H. Saputra. 1998. Serat Panji Angreni; Aspek kesastraan. Depok: Fakultas Sastra Universitas Indonesia.

Karsono H. Saputra. 2014. Panji Angronakung. Jakarta: Perpusnas.

Kieven, L. 2013. Following the cap-figure in Majapahit temple reliefs; A new look at the religious function of East Javanese temples, fourteen th and fifteenth centuries. Leiden: Brill. [Open access as pdf: http:/ / www.brill.com/following-capfigure-majapahit-temple-reliefs.]

Kieven, L. 2014a. Menelusuri figur bertopi dalam relief candi zaman Majapahit; Pandangan baru terhadap fungsi religius candi-candi periode Jawa Timur abad ke-14 dan ke-15. Jakarta: EFEO. [Translation of Kieven 2013 from English to Indonesian language.]

Kieven, L. 2014b. "Simbolisme cerita Panji dalam relief-relief di candi zaman Majapahit dan nilainya pada masa kini", in: Perpustakaan Nasional Republik Indonesia, Prosiding Seminar Naskah Kuna Nusantara "Cerita Panji sebagai warisan dunia" di Jakarta, 28-29 Oktober, pp. 263-280. Jakarta: PerpusNas. 
Kieven, L. 2016. "Panji and Candrakirana lost in separation - three ancient East Javanese sculptures", Amerta Jurnal Penelitian dan Pengembangan Arkeologi (Journal of Archaeological Research and Development) Vol 34 No. 1 (Juni): 31-48. [Jakarta: Pusat Penelitian Arkeologi Nasional Kementerian Pendidikan dan Kebudayaan.]

Kieven, L. 2017a. “Getting closer to the primordial Panji? Panji stories carved in stone at ancient Javanese Majapahit temples", Proceedings of the Conference "The Panji/Inao traditions in Southeast Asia, Bangkok2-6 March 2013". [Bangkok: SEAMEO-SPAFA; SPAFA JOURNAL (online access) Vol 1 (2017); Online Journal: http://www.spafajournal.org/index.php/spafajournal/article/ view/172.]

Kieven, L. 2017b. Menelusuri Panji di candi-candi. Jakarta: Gramedia. [Re-print of Menelusuri figur bertopi dalam relief candi zaman Majapahit 2014.]

Kieven, L. 2018. Menelusuri Panji dan Sekartaji - Tradisi Panji dan proses transformasinya pada zaman kini. Yogyakarta: Ombak.

Kuhnt-Saptodewo, Sri. 2007. "Getanzte Geschichte", in: E. Streifeneder and A. Missbach, Indonesia - The presence of the past, pp. 267-286. Berlin: Regiospectra.

Kurin, Richard. 2004. "Safeguarding intangible cultural heritage in the 2003 UNESCO Convention; A critical appraisal”, Museum International 56: 66-77.

Lowenthal, David. 1985. The past is a foreign country. Cambridge: Cambridge University Press.

Lowenthal, David. 2015. The past is a foreign country - Revisited. Uppsala: Uppsala Universitet.

Matusitz, Jonathan and Lauren Palermo. 2014. "The disneyfication of the world; A globalisation perspective", Journal of Organisational Transformation E Social Change 11/2: 91-107.

Mills, J.V.G. 1970. Ma Huan, Ying-yai Sheng-lan. London: Hakluyt Society.

Noriah Mohamad. 2017. Panji Jayengtilem. Kuala Lumpur: Dewan Bahasa dan Pustaka.

Perpustakaan Nasional Republik Indonesia. 2014a. Prosiding Seminar Naskah Kuna Nusantara "Cerita Panji sebagai warisan dunia" di Jakarta pada 28-29 Oktober 2014. Jakarta: PerpusNas.

Perpustakaan Nasional Republik Indonesia. 2014b. Hikayat Mesa Gimang (W 138); Suntingan Teks. Jakarta: PerpusNas.

Pigeaud, Th.G. 1938. Javaanse volksvertoningen; Bijdrage tot de beschrijving van land en volk. Batavia: Volkslectuur.

Poerbatjaraka, R.M.Ng. 1940. Pandji-verhalen onderling vergeleken. Bandoeng: Nix. [Bibliotheca Javanica 9.]

Poerbatjaraka, R.M.Ng. 1968. Tjerita Pandji dalam perbandingan. Jakarta: Gunung Agung.

Puaksom, Davisakd. 2007. The pursuit of Java; Thai Panji stories, Melayu lingua franca and the question of tanslation. PhD thesis, National University of Singapore.

Ras, J.J. 1973. "The Panji romance and W.H. Rassers; Analysis of its theme", Bijdragen tot de Taal-, Land-en Volkenkunde 129: 411-456. 
Rassers, W.H. 1922. De Pandji-roman. Antwerpen: De Vos-Van Kleef.

Robson, S.O. 1971. Wangbang Wideya; a Javanese Pañji romance. The Hague: Nijhoff.

Ross, Laurie. 2016. The encoded Cirebon mask; Materiality, flow, and meaning along Java's Islamic northwest coast. Leiden: Brill.

Roudometof, Victor. 2016. Glocalization; A critical introduction. London: Routledge.

Satyawati Suleiman. 1978. The pendopo terrace of Panataran. Jakarta: Proyek Pelita Pembinaan Kepurbakalaan dan Peninggalan Nasional.

SEAMEO-SPAFA. 2017. Proceedings of the Conference" The Panji/Inao traditions in Southeast Asia, Bangkok 2-6 March 2013", SPAFA Journal. Bangkok: SEAMEOSPAFA. [A few articles available online: http://www.spafajournal. org/index.php/spafajournal/article/view/172/565; Homepage of the conference and festival: http:/ / www.seameo-spafa.org/panjiinaosoutheast-asian-performancetheatre-and-dance/.]

Serrurier, L. 1896. De wajang poerwa. Leiden: Brill.

Smith, Laurajane (ed.). 2009. Intangible heritage. London: Routledge.

Stutterheim, W.F. 1925. Rāma-Legenden und Rāma-Reliefs in Indonesien. München: Müller.

Stutterheim, W.F. 1936a. "Voorloopig bericht omtrent enkele vondsten op den Penanggoengan in 1935", Djåwå; Tijdschrift van het Java-Instituut 16: 194-200.

Stutterheim, W.F. 1936b. "Een Pandji-kop uit de 15e eeuw", Maandblad voor Beeldende Kunsten 13: 329-335.

Stutterheim, W.F. 1989. Rama-legends and Rama-reliefs in Indonesia. New Delhi: Indira Gandhi National Centre for the Arts, Abhinav Publications.

UNESCO. 2003. Convention for the safeguarding of the intangible cultural heritage. [Http://www.unesco.org/new/en/communication-and-information/ memory-of-the-world/register/full-list-of-registered-heritage/registeredheritage-page-7/panji-tales-manuscripts/.]

Vickers, Adrian. 2005. Journeys of desire; A study of the Balinese text Malat. Leiden: KITLV Press.

Vickers, Adrian. 2009. Peradaban pesisir; Menuju sejarah budaya Asia Tenggara. Yogyakarta: Pustaka Larasan and Udayana University Press. 


\section{APPENDIX}

A List OF MAJOR EVENTS AND ACTIVITIES ON PANJI

mid-1990s informal discussions around environmentalist Suryo Wardhoyo Prawiroatmodjo from PPLH Seloliman/Trawas on the Panji topic and ideas of revitalization.

1996 start of my research on the Panji reliefs at Majapahit temples.

2004 meeting of "Panji Enthusiasts" in Surabaya, initiated by Suryo W. Prawiroatmodjo, co-initiated by artist Suprapto Suryodarmo from Solo, and archaeologist Lydia Kieven.

2007 Panji Festival and seminar: "International Seminar on Local Wisdom from Panji Era" at Universitas Merdeka Malang, Tourism Campus, initiated by Suryo W. Prawiroatmodjo and Lydia Kieven, organized by Dr Gunawan Wibisono and Dr Hery Kurniawan;

Wayang beber workshop for children in Trawas, initiated by Suryo W. Prawiroatmodjo;

Workshop "Tata Busana pada zaman Majapahit" with students of design at House of Sempoerna Surabaya, initiated by Suryo W. Prawiroatmodjo in cooperation with Lydia Kieven;

Panji dance choreography at PPLH in Trawas, initiated by Suprapro Suryodarmo;

Wayang topeng performance at Padepokan Mangundharmo, Tumpang; by Ki Soleh Adi Pramono.

2008 Panji programme at PPLH in Trawas, in cooperation with Suprapto Suryodarmo and Henri Nurcahyo.

2010 Seminar at Candi Panataran; in combination with a workshop for children: paintings of motives in the temple complex, initiated by Henri Nurcahyo.

2010 and later on

Workshops for schoolclasses at the Majapahit Museum in Trowulan, thematizing local knowledge and wisdom, including the Panji theme; conducted by Suryo W. Prawiroatmodjo.

2013-2015 Panji Festival in Blitar: performances of choreographies created by school-classes on a Panji theme, seminar on Panji; conducted by Wima Brahmantyo, Kholam Shiharta, and Rahmanto Adi, art's association of Blitar.

2014 First meeting of Panji friends (Pencinta Panji) in East Java, with the intention to interconnect groups, individuals and activities in the field of Panji, establishing a website for publications and a digital museum on Panji; cooperation of Agus Wiyono, Bagoes Brotodiwirdjo, and Lydia Kieven.

2014 and ongoing:

performances of Jantur Panji Udan (start in the region of Klaten); conducted by artist Agus Bimo Prayitno. 
2014 Introduction of the curriculum of "Panji Studies" at the Department of Tourism at University Ciputra, Surabaya; head: Dewa Gde Satrya, cooperation with archaeologist Dwi Cahyono, Universitas Negeri Malang.

2014 Festival "Panji - the Greatest", and seminar "Topeng Panji" in Surakarta, cooperation of Balai Soedjatmoko (Ardus Sawega) and Semarak Candrakirana Foundation (Irawati Kusumorasri); parts of the festival program also presented in Malang.

2014 National Library in Jakarta: Seminar on Panji along with an exhibition of Panji manuscripts from the library, and performances; as initial step of the application of the Panji tales manuscripts for registration by UNESCO as Memory of the World, consultant Wardiman Djojonegoro, former minister of cultural affairs of Indonesia.

2015 Second Meeting of "Pencinta Panji" in Malang.

2015 "Tour Panji": visit of temples and sites in the region of Blitar having Panji reliefs; initiated by Yayasan Pring Woeloeng, conducted by Lydia Kieven.

2015 City and District of Kediri: events including performances and rituals having the Panji theme: "Panji Pulang Kampung", "Panji Bersih Desa"; cooperation Kabupaten Kediri, Jamran Ida, Henri Nurcahyo and others.

2016 Performances of traditional wayang beber in Pacitan, and of contemporary forms, carried on throughout the following years; by Rudhi Prasetyo, Ganjar Abunawas, Dani Iswardana, Supani Guno Darmo.

2017 Opening of the Panji Museum in Malang, East Java; founded by Dwi Cahyono. ${ }^{51}$

2017 Festival Panji Nusantara in Kediri (July), conducted by the Department of Tourism and Culture of the Province of East Java, by the city and district Kediri, and by the National Library; grand finale: seminar and performances in Jakarta (August).

2017 Opening of Museum Wayang Beber Sekartaji in Bantul/Yogyakarta: exhibition of paintings in the wayang beber-style, workshops for schoolclasses; founder: Indra Suroinggeno, cooperation with paintress Ibu Ning from Surakarta.

2017 (October):

Registration of the Panji tales manuscripts as Memory of the World by UNESCO.

\footnotetext{
${ }^{51}$ Dwi Cahyono from Museum Panji is a person different from archaeologist Dwi Cahyono, both in Malang. In the Panji communities the earlier is called "Dwi Cahyono Inggil" (Inggil is the name of his restaurant in Malang), the latter "Dwi Cahyono arkeolog".
} 
2018 International Panji Festival celebrating the UNESCO registration: Performances by dance groups from Indonesia, Thailand and Cambodia, workshops; in Bali, East Java, Yogyakarta; final event including a two-days International Panji Seminar in Jakarta 10-11 July; conducted by the Culture Ministry of Indonesia, under guidance of Wardiman Djojonegoro; with international participants.

2018-2019 A number of Panji-related events by local communities, for example: "Spirit Panji" in Tulungagung in August; initiated by archaeologist Dwi Cahyono;

Jejak Mirigambar: performances and workshop for children at the site of Candi Mirigambar having Panji reliefs; initiated by Huda Faujan and komunitas Tulungagung;

Wayang beber workshops at SMAN 1 Pacet, Mojokerto, initiated by Arief Budi Santono cooperation with Dani Iswardana and others.

2019 Festival Panji Nusantara (National Panji Festival) in East Java (July): Performances, exhibition, seminars in Malang, Tulungagung, Kediri, with national participants.

INTERNATIONAL PROGRAMMES ON PANJI IN OTHER COUNTRIES

2013 Conference and festival: "Seminar and Performances of a Shared Heritage: The Panji/Inao Traditions in Southeast Asia 2-6 March 2013", organized by SEAMEO-SFAFA (Southeast Asian Ministers of Education Organization).

2015 Seminar "Indonesian Super Hero: Cerita Panji", National German Library Berlin, making part of the program "Indonesia as Special Guest at Frankfurt Bookfair", in cooperation with National Museum Jakarta.

2017 Panel on "Panji and cultural patterns in Southeast Asia" at the conference of EuroSEAS in Oxford, England, in August; initiated and organized by Lydia Kieven. ${ }^{52}$

2017 Exhibition on the history and contemporary developments of wayang beber, by Croatian anthropologists Tea Škrinjarić and Marina Pretković, Ethnological Museum in cooperation with KBRI Zagreb.

2018 Panji Symposium at the University Leiden; cooperation between University Library, KITLV, and the Journal of Wacana of the University of Indonesia; including the performance of Jantur Panji Udan by the artist group "Seni Jantur" (September).

\footnotetext{
${ }^{52}$ The publication of the double issue on Panji stories by Wacana, Journal of the Humanities of Indonesia was initiated as an outcome of this conference panel.
} 
2018 Tour of the group Seni Jantur from Klaten in the Netherlands and Germany: performances and workshops (September to October); organized by Lydia Kieven.

House of Indonesian Cultures (Embassy of Indonesia, Berlin), two weeks event: "Panji Lost and Found", including: exhibition on wayang beber by Croatian anthropologists, workshop, and performance of the group Seni Jantur; presentation of Panji manuscripts in the German National Library and seminar on the revitalization of the Panji tradition.

2019 Panji/Inao: Preserving and Reviving the Shared Heritage of South East Asia, Chulalongkorn Asian Heritage Forum, Bangkok 20-21 July.

A few websites and facebook groups have been established..$^{53}$ A great number of press releases were published over the years.

${ }^{53}$ www.ppanji.org; www.budayapanji.com; www.waybemetro.wordpress.com; facebooks groups: Pencinta Panji, Sahabat Panji dan Sekartaji, Wayang Beber Kota, Wayang Beber Metropolitan, Panji Sakbendino, wayangbeber, and others.

See footnotes above nos. 12 and 13. 